\title{
A modernidade de Grande Sertão: Veredas ${ }^{1}$
}

\author{
Marli FANTINI SCARPELLI \\ Universidade Federal de Minas Gerais2
}

RESUMO: EMBORA EDITADO EM 1956, CERCA DE VINTE ANOS DEPOIS DE VIDAS SECAS, GRANDE SERTÃO: VEREDAS GUARDA COM TAL ROMANCE MUITAS AFINIDADES, SOBRETUDO NO ENFOQUE REGIONALISTA. TODAVIA, A DESPEITO DE O REGIONALISMO DE ROSA JÁ DESLIZAR PARA A TENSÃO ENTRE O REGIONAL E O UNIVERSAL, ELE NÃO DEIXA TAMBÉM DE RETRATAR A GEOPOLITICA DA DEGRADAÇÃO AMBIENTAL E HUMANA NA REGIÃO DO CERRADO, TEMA CABALMENTE EXPLORADO NO PRESENTE SÉCULO, O QUE TORNA GRANDE SERTÃO: VEREDAS, COMO OUTRAS OBRAS-PRIMAS, UM ROMANCE ATUAL NO SÉCULO XXI.

ABSTRACT: ALTHOUGH EDITED IN 1956, ABOUT 20 YEARS AFTER VIDAS SECAS IBARREN LINES, GRANDE SERTÃO: VEREDAS ITHE DEVIL TO PAY IN THE BACKLANDS HOLDS MANY SIMILARITIES WITH THE PREVIOUS, ESPECIALLY IN ITS REGIONALIST FOCUS. HOWEVER - DESPITE THE FACT THAT ROSA'S REGIONALISM ALREADY SLIPS TO THE TENSION BETWEEN THE REGIONAL AND THE UNIVERSAL - IT ALSO SHOWS THE GEOPOLITICAL ASPECTS OF THE HUMAN AND ENVIRONMENTAL DEGRADATION THAT IS FOUND IN THE CERRADO REGION, A THEME THAT IS FULLY EXPLORED IN THE PRESENT CENTURY, WHICH MAKES GRANDE SERTÃO: VEREDAS, AS OTHER MASTERPIECES, A "CONTEMPORARY" NOVEL IN THE XXI CENTURY.

PALAVRAS-CHAVE: LETRAS E ARMAS - REGIONAL E TRANSREGIONAL - LITERATURA E MEIO AMBIENTE

KEY-WORDS: LETTERS AND WEAPONS - REGIONAL AND TRANS-REGIONAL - LITERATURE AND ENVIRONMENT

\footnotetext{
${ }^{1}$ Este ensaio foi publicado, com pequenas diferenças, sob o título de "Guimarães Rosa: $50^{\circ}$ de Grande sertão: veredas", na revista $O$ eixo e a roda, n. 8, do POSLIT, FALE/UFMG, Especial sobre Guimarães Rosa, 2006.

${ }^{2}$ Marli Fantini Scarpelli é professora de Teoria da Literatura e Literatura Comparada da Faculdade de Letras da UFMG e pesquisadora do CNPq, com Bolsa de Produtividade em Pesquisa, graças à qual este trabalho pôde ser realizado. Dentre suas publicações, destaca-se o livro Guimarães Rosa: fronteiras, margens, passagens (Senac/Ateliê, 2004).
} 


\section{Grande sertão: veredas, no seu cinqüentenário}

ano de 2006 é uma data histórica relevante para as letras brasileiras e para os admiradores de João Guimarães Rosa. Corpo de baile e Grande sertão: veredas, duas obras rosianas de grande fôlego, vieram a lume, respectivamente, em janeiro e maio de 1956. Neste ano em que se comemora o cinqüentenário da primeira edição das duas obras-primas rosianas, ambas continuam merecidamente recebendo homenagens e comemorações em todo o Brasil do real, pouco afeito às dimensões simbólicas em geral e às letras em particular. Não podemos, todavia, esquecer o bem próximo ano de 2008, o qual será também emblemático para nossas letras. Comemoraremos, então, o centenário dos dois gigantes que alçaram a literatura brasileira dos dois últimos séculos a patamares universais.

Estamos tratando dos cem anos de falecimento de Machado de Assis, criador da Academia Brasileira de Letras e seu presidente vitalício, cujo último livro - publicado em 1908, ano da morte do autor - teve como protagonista o conselheiro Aires, embaixador brasileiro servindo no exterior, que retorna ao Brasil depois de se aposentar. Coincidentemente, nesse mesmo ano nasce João Guimarães Rosa, que, diplomata de carreira, representará o Brasil em vários países como secretário de embaixada, cônsul e finalmente embaixador, como nosso conselheiro mais ilustre, que, diferentemente de Rosa, somente habitou o Memorial de Aires de Machado.

Memoráveis são, desse modo, os idos de 1908, a evocar uma imaginária troca de bastões entre esses dois campeões, não da economia ou da política, nem mesmo das disputas esportivas que começam a honrar o nome do Brasil no exterior. Trata-se antes da esfera literária, com fumos de diplomacia, a única talvez a conferir ao país uma honrosa saída para os vícios de origem como aqueles em decorrência dos quais ele (o Brasil) se vê ainda hoje contaminado: afinal, são séculos de colonização, tráfico de escravos, armas, drogas e influências. Enfim, ao acender uma luzinha na nossa obscuridade, a via aberta por esse duplo centenário poderá apontar uma saída (embora intermitente e tênue) para a bruteza de um real que parece nunca deixar de abrir suas negras asas sobre nós. Posto que tartamudeantemente, a literatura de nossos melhores escritores é uma das poucas veredas a chancelar nosso ingresso no universo da consciência, do simbólico, da reflexão sobre nossa 
história e nossos valores culturais. É nessas veredas que visamos apear sob o influxo do cinqüentenário de 2006 e do centenário de 2008.

\section{Ler Guimarães Rosa: reler um clássico}

Em 16 de novembro de 1967, já consagrado nacional e internacionalmente como escritor e diplomata do Itamarati, com várias e relevantes representações do Brasil no exterior, Rosa se torna imortal ao tomar posse na Academia Brasileira de Letras. Fazia quatro anos que a posse vinha sendo protelada, visto Rosa sentir-se perseguido pelo pressentimento de que o impacto em face da imortalidade o levaria à morte. De fato, a pressão alta, o coração debilitado e a irrepresável emoção causam-lhe um enfarte, em decorrência do qual vem a falecer, no dia 19 de novembro, três dias depois da posse. No discurso pronunciado no velório de um colega da Faculdade de Medicina, 41 anos antes da posse na Academia, Rosa provoca seus interlocutores com esta que viria a ser uma de suas mais citadas máximas: "As pessoas não morrem, ficam encantadas". Paradoxalmente, depois de se alçar à imortalidade e transcender a outras esferas, o próprio Guimarães Rosa finalmente se encanta. Hesitantes como Drummond em face dos mistérios de Rosa, "Ficamos sem saber o que era João / E se João existiu de se pegar” (ANDRADE, 1967).

Homem de cultura exemplar, pesquisador contumaz desde muito jovem, Guimarães Rosa soube, como raros escritores, conciliar sua reconhecida inventividade com uma obstinada pesquisa a fontes da mais diversificada procedência, aplicando-se, ademais, à permanente e disciplinada aprendizagem de diversos idiomas. A par de suas pesquisas, ele deteve-se continuamente no esforço de depurar, refinar e potencializar a língua que dá suporte a sua obra literária. O ineditismo de suas construções sintáticas, a mescla vocabular, a revitalização de palavras gastas, o aproveitamento de virtualidades fônicas tanto do português quanto de outros idiomas, entre outros procedimentos, revelam um escritor empenhado em surpreender e empregar, em sua textura poética, formações lingüísticas singulares, emergidas de várias temporalidades e de diferentes usos, visando, dessa forma, atingir um ideal de inteligibilidade universal. 
No cinqüentenário de nascimento do Grande sertão: veredas, inúmeras qualidades lhe podem ser crescentemente reconhecidas. A capacidade de dar visibilidade a potencialidades não realizadas; de agenciar novas redes de sentido; de conciliar experiência e discurso - sem perder de vista a coexistência muitas vezes contraditória entre essas duas instâncias - são atributos em que se encaixa perfeitamente a obra-prima rosiana. Assim sendo, as obras do escritor mineiro vêm-se revelando, em diferentes tempos e distintas formas de recepção, sempre novas, inesperadas, inéditas.

A idéia de integrar, numa mesma rede multíplice e infinita, conhecimento e emoção, várias experiências e estilos, em que tudo pode ser continuamente remexido e reordenado de todas as maneiras possíveis, sob o princípio de amostragem potencial do narrável, engendra a totalidade potencial, conjectural, multíplice dos hiper-romances que emblematizam a literatura deste novo milênio. Móvel e remanejável como um tabuleiro de xadrez, a cartografia rosiana agencia, dessa forma, infinitas combinações territoriais, cujo traçado aceita a intervenção simultânea de negociações e acaso. Hábil estrategista, nosso escritor-diplomata Rosa maneja os lances mediante os quais pode reciclar os lugares fixos da geografia e da história, para criar múltiplas redes de sentido e relações de intersubjetividade, que, por sua vez, se enredam nas combinações recursivas entre ficção e referenciais geopolíticos, como se lê nesta passagem de Grande sertão: veredas: "Esses gerais são sem tamanho. Enfim, cada um o que quer aprova, o senhor sabe: pão ou pães, é questão de opiniães... O sertão está em toda parte” (ROSA, 1984:8).

Reler um clássico como o romance Grande sertão: veredas, de Guimarães Rosa, é como lê-lo pela primeira vez, graças ao caráter inusitado de sua linguagem e sobretudo de sua estruturação, cuja cadeia interativa abre elos para inserir novas redes e leitores.

\section{Grande sertão: veredas: literatura e meio ambiente}

Dentre nossos romances modernistas, Grande sertão: veredas é certamente o que provocou maior abalo nos leitores e na crítica literária. Nacional e internacionalmente consagrada, a obra-prima rosiana foi traduzida em quase todos os idiomas vivos (e em alguns mortos), inscrevendo-se, assim, no cânone univer- 
sal. Embora editado em 1956, cerca de vinte anos depois de Vidas secas, o Grande sertão guarda com a obra de Graciliano Ramos muitas afinidades temáticas e estruturais, sobretudo no enfoque regionalista. Todavia, o regionalismo de Rosa apresenta a singularidade de já deslizar para o transregionalismo, ou melhor, para a tensão entre o regional e o universal. A despeito disso, ele, em consonância com Vidas secas, não deixa de retratar a geopolítica da degradação ambiental. O cenário do romance de Graciliano Ramos é o Nordeste com suas secas avassaladoras. Já o Grande sertão: veredas pode ser referencialmente localizado na região do cerrado, com especial acento no sertão de Minas Gerais. O tema da degradação ambiental, recorrentemente explorado no presente século, torna Grande sertão: veredas, dentre outras razões já apresentadas, um romance ainda atual no século XXI, o que justifica a relevância de sua leitura e sua comemoração por ocasião do cinqüentenário de sua primeira edição.

A narrativa do romance Grande sertão: veredas constitui uma espécie de "testemunho", resultante da entrevista concedida por Riobaldo, narradorprotagonista do romance, a um forasteiro culto que o procura, desejando ouvir dele notícias do sertão arcaico, regido pela lei dos latifundiários e seus belicosos jagunços. A despeito de ser, ao tempo da entrevista, um respeitado fazendeiro e quase barranqueiro, Riobaldo tornara-se, depois de muita luta e muitos pactos, inclusive com o diabo, uma figura legendária na pele do "Urutu-Branco", um beligerante chefe de jagunços. A seu entrevistador, Riobaldo avisa que, se ele veio com a ilusão de descobrir um Brasil simultaneamente primitivo e idílico, a salvo do degradante impacto da modernização, é melhor que desista, pois o "paraíso" já foi contaminado. No romance, a negatividade da mudança é, deste modo, denunciada:

O senhor sério tenciona devassar este mar de territórios, para sortimento de conferir o que existe? Tem seus motivos. Agora - digo por mim - o senhor vem, veio tarde. Tempos foram, os costumes demudaram. Quase que, de legítimo leal, pouco sobra, nem não sobra mais nada. Os bandos bons de valentões repartiram seu fim; muito que foi jagunço por aí pena, pede esmola. Mesmo os vaqueiros duvidam de vir no comércio vestidos de roupa inteira de couro, acham que o traje de gibão é feio e capiau. E até o gado no grameal vai minguando menos bravo, mais educado. [...] Sempre nos gerais, é à pobreza, à tristeza (ROSA, 1984: 24). 


\section{Grande sertão: veredas: testemunho de uma outra voz}

Meio jornalista, meio escritor, meio etnólogo, o entrevistador de Riobaldo anota em suas cadernetas de campo o depoimento desse sertanejo com estatura mítica e heróica, que se impusera a tarefa de livrar o sertão do mal da jagunçagem. A despeito de ter cumprido sua missão e de ser, em homologia com outros heróis bíblicos e/ou míticos, um avatar dos valores de sua comunidade e, enquanto tal, responsável por transformações de ordem ética, política e sociocultural, Riobaldo possui, diferentemente dos heróis canônicos, uma estatura bastarda, periférica, reificada, decorrente de suas condições de subdesenvolvimento, subumanidade e subalternidade. Não possuindo a autoridade da narrativa épica ou da crônica oficial, o testemunho do ex-jagunço só se tornará exemplar e só terá assegurada sua aura caso entre em interlocução com uma voz legitimadora de sua fala. É sobretudo nesse sentido que o romance se constrói como um grande diálogo, assumindo, contudo, a forma de monodiálogo ou "diálogo pela metade" (SCHWARZ, 1991: 38). Ou seja, ainda que haja uma entrevista, as únicas palavras que se ouvem são as do entrevistado, evidenciando-se, desse modo, ser esta a hora e a vez de o sujeito subalterno da história pronunciar sua voz e sua versão pessoal de acontecimentos por ele vividos e testemunhados.

Desde seu início, o romance assume uma estrutura inusitada. Ele se inicia com uma frase nominal mínima: um travessão seguido de um único vocábulo e ponto: “- Nonada". E vai terminar com "travessia”, palavra seguida por um ícone, pelo signo de infinito, de hibridismo, ou daquela serpente que morde a própria cauda. Tal signo sugere, dentre outras, a idéia de que o romance estará abrindo os elos de sua cadeia interativa para novas travessias e para nelas inserir novas redes e novos leitores do diabólico pacto ficcional por ele proposto. Seja no início, seja no meio ou no final de Grande sertão: veredas, há uma intrincada teia narrativa obrigando cada passagem a interagir com uma infinda e recursiva cadeia hipertextual, que não só remete a si mesma, como também à heterogeneidade conflitiva do "sertão-mundo", em que tudo sempre atravessa e sempre recomeça, conforme sugere a passagem abaixo: 
tário?!"

Então êle sorriu, o pronto sincero, e me vale me respondeu:

- "Tem cisma não. Pensa para diante. Comprar ou vender, às vêzes, são as ações que são as quase iguais..."

$\mathrm{E}$ me cerro, aqui, mire e veja. Isto não é o de um relatar passagens de sua vida, em tôda admiração. Conto o que fui e vi, no levantar do dia. Auroras.

Cerro. O senhor vê. Contei tudo. Agora estou aqui, quase barranqueiro. Para a velhice vou, com ordem e trabalho. Sei de mim? Cumpro. 0 Rio de São Francisco que de tão grande se comparece - parece é um pau grosso, em pé, enorme... Amável o senhor me ouviu, minha idéia confirmou: que o Diabo não existe. Pois não? 0 senhor é um homem soberano, circunspecto. Amigos somos. Nonada. 0 diabo não há! É o que eu digo, se fôr... Existe é homem humano. Travessia.

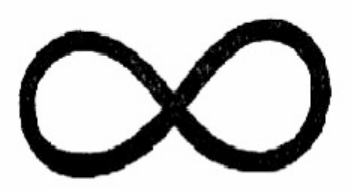

Figura 1. Detalhe de página. Reproduzido de: ROSA, Guimarães. Grande sertão: veredas. 3. ed. Rio de Janeiro: José Olympio, 1964. p. 460.

Letras e armas

Quando lhe morre a mãe, Riobaldo, ainda menino, é levado para a fazenda do pai, o latifundiário Selorico Mendes. Não se assumindo como tal, este se apresenta ao filho como "padrinho". Nesse sentido, Riobaldo é um dos mui- 
tos "afilhados" de latifundiários como Selorico Mendes. Trata-se de filhos bastardos oriundos de relações quase sempre forçadas entre o patrão e suas dependentes, relações por meio das quais o romance suscita a denúncia de uma das heranças coloniais, sob a forma de dependência econômica e sociocultural, ainda resistente ao tempo encenado no romance, ou seja, entre o final do século XIX e as décadas iniciais do século XX.

Com a mediação do "padrinho", nosso herói bastardo aprenderá a contar histórias e a manejar com excelência as armas. Introduzir o "afilhado" Riobaldo no manejo de armas é a forma como Selorico institui laços de proteção e compensação para com o filho "ilegítimo", preparando-o também para ocupar seu lugar no latifúndio:

Queria que eu aprendesse a atirar bem, e manejar porrete e faca. Me deu logo um punhal, me deu uma garrucha e uma granadeira. Mais tarde, me deu até um facão enterçado, que tinha mandado forjar para próprio, quase do tamanho de espada e em formato de folha de gravatá. (ROSA, 1984: 105)

É, portanto, sob o signo da fala, da beligerância e do suplemento fálico, que Riobaldo se insere nessa arcaica tradição rural, cuja "malignidade", numa reviravolta bélica, ele próprio tratará mais tarde de combater. Acreditando faltarem ao "afilhado" as habilidades necessárias a um futuro latifundiário, Selorico Mendes decide também que ele estude, designando o Mestre Lucas, do Curralinho, para ensinar-lhe as primeiras letras: "Baldo, você carecia mesmo de estudar e tirar carta-de-doutor, porque para cuidar do trivial você jeito não tem" (ROSA, 1984: 106). Longe de casa, ele se prepara, todavia, para se tornar o jagunço letrado que deverá conhecer um pouco de tudo para enfrentar o mundo de constantes guerras, mudanças e travessias, com o qual logo se verá confrontado:

Soletrei, anos e meio, meante cartilha, memória e palmatória. Tive Mestre Lucas, no Curralinho, decorei gramática, as operações, regra-de-três, até geografia e estudo pátrio. Em folhas grandes de papel, com capricho desenhei bonitos mapas. (ROSA, 1984: 14)

A habilidade de Riobaldo no uso das palavras e das armas corresponde a um dos mais paradigmáticos ideários de Rosa, a manifestar-se na crença de 
que sua literatura, em face do duplo desafio de restauração e renovação da língua, teria a capacidade de modificar a realidade. Ele afirma numa entrevista de 1965, em Gênova, a Günter Lorenz: "Minha língua brasileira é a língua do homem de amanhã, depois da purificação. Por isso devo purificar minha língua. Minha língua [...] é a arma com a qual defendo a dignidade do homem [...]. Somente renovando a língua é que se pode renovar o mundo" (ROSA, 1994: 52).

Tão certeiro no manejo das armas quanto no das palavras, o jagunço letrado usa as primeiras para mirar, com seus implacáveis tiros, o "escuro" da malignidade jagunça. Quanto às palavras, estas serão empregadas tanto para cerzir os rombos abertos pelos tiros do herói jagunço, quanto para retramar a teia da história, desencadeando, assim, uma nova rede de sentidos. Enfim, ao se apropriar das "letras" e das "armas" legadas pelo pai, o nosso herói pode combater o sistema que aquele representa, numa evidente metáfora à dependência colonial que deve ser combatida a partir da apropriação ladina e insurgente dos seus próprios aparatos bélicos e ideológicos. Tornando-se o "Cerzidor", certeiro nos tiros e nas palavras, Riobaldo se prepara para ocupar e desocupar o lugar do pai.

\section{Heróis nas armas e nas letras}

Além da involuntária herança colonial e bastarda, o narrador-protagonista de Grande sertão: veredas é herdeiro voluntário de muitas outras histórias e tradições, revelando, todavia, afinidade com a tradição manchega e um forte parentesco com muitos intelectuais revolucionários latino-americanos. As afinidades certamente resultam do rigor seletivo do autor e são encarnados por heróis emblemáticos, a exemplo de Dom Quixote de la Mancha e de Che Guevara. Estes, como é sabido, nada possuem de seu, a não ser um cavalo (no primeiro caso) ou uma moto (no segundo), veículos (e ícones) por meio dos quais cada um deles materializa sua viagem de descoberta, mapeamento e desconstrução do mundo circundante.

Curiosamente, a tradição de viagem ficcionalmente fundada pelo "Cavaleiro da Triste Figura”, em 1605, vem, a partir de então, estabelecendo fortes elos entre a realidade, a ficção e a utopia político-revolucionária. Trata-se de um tipo de expe- 
riência criativamente apropriada por muitos heróis viajantes, parentes filosóficos de Riobaldo e Guevara, dois conhecidos atores latino-americanos, oriundos, cada um por sua vez, da ficção e, respectivamente, da realidade histórica.

Em 1951, Guevara transita pela América Latina junto com o amigo Granado, numa motocicleta, sintomaticamente associada a "Rocinante", 3 o cavalo de Dom Quixote, remetendo a uma herança e a uma tradição com a qual o revolucionário argentino se mostra identificado (cf. JIMÉNEZ). Na carta de despedida a seus filhos, Che explicita sua filiação à tradição manchega quando descreve sua última e mais quimérica viagem. Alicerçado na utopia libertária de povos oprimidos como os latino-americanos, ele trava sua batalha final, chancelado por uma consciência mais aguda sobre seu ideário de intelectual revolucionário e por um frágil escudo sob cuja proteção não logrou salvar-se. Seu veículo é o não menos frágil cavalo de Dom Quixote:

Uma vez mais sinto sob os calcanhares as costelas de Rocinante. Retorno para a estrada com o escudo no braço. Nada de especial mudou, exceto que estou mais cônscio, meu marxismo está mais arraigado e mais cristalizado. Creio na luta armada como única solução para os povos que lutam para se libertarem e sou coerente com minhas crenças. ${ }^{4}$

Não diferentemente deste seu "hermano" revolucionário ou de Dom Quixote, avô sonhador de ambos, Riobaldo empunha suas armas numa das mãos, e na outra sempre traz um livro, uma cantiga, um poema. Sobre a cantiga de Siruiz, ouvida pela primeira vez na fazenda de seu "padrinho", o nosso herói afirma a seu entrevistador: "Aquilo molhou minha idéia. Aire me adoçou tanto, que dei para inventar, de espírito, versos de outra qualidade. Fiz muitos, montão" (ROSA, 1984: 113). Considerando o parentesco entre os três heróis, não é custoso lembrar que Riobaldo, já Chefe Urutu-Branco, batiza seu cavalo de "Siruiz", nome da cantiga predileta do jagunço letrado.

\footnotetext{
${ }^{3}$ Curiosamente, no filme Diários de motocicleta, de Walter Salles, pouco antes de partir para sua viagem com Che Guevara, Granado compara sua motocicleta com o cavalo Rocinante, de Dom Quixote.

4 "Carta de despedida de Che para seus filhos que deveria ser lida por eles somente depois de sua morte". Disponível em: <http://www.cheguevara1.hpg.ig.com.br/cartas.htm>. Acesso em: 15 out. 2005.
} 
Dom Quixote empunha sua espada; armas são manejadas por Riobaldo e Guevara. Contudo, um e outros, em comum, não deixam de amainar suas relações com um mundo de hostilidades e ameaças, sob a mediação de livros e poemas. Todos conhecemos a tensão entre a dureza da guerra e a suavidade do sentimento que, nesse sentido, Guevara expressa na frase: "Hay que endurecerse, pero sin perder la ternura jamás". Não obstante semelhantes correspondências, Riobaldo, ex-jagunço e bastardo, que vivia "cachorrando pelo sertão", não é fidalgo como Quixote nem médico como Guevara. Assim sendo, não possui a autoridade da narrativa épica ou da crônica oficial, e seu testemunho só se tornará exemplar e só terá assegurada sua aura caso entre em interlocução com uma voz que legitime sua experiência.

\section{Pesquisa e inventividade de Rosa}

Quando reconstituímos o ambiente literário, a vida intelectual e profissional de Guimarães Rosa, tendo sobretudo em vista o constante exercício de conjugar, em sua escrita, diferentes formas de conhecimento e formações discursivas de prestígio diferenciado (oral e escrito, popular e erudito, saber mitopoético e saber epistemológico, intuição e razão), não podemos ignorar a contribuição capital de sua obra ficcional para a ampliação do conceito de literatura e cultura. A partir, por exemplo, de seu acervo epistolar, é possível identificar-lhe um perfil humano, intelectual e profissional marcado pelo constante e disciplinado cuidado de si e do outro, o sentimento de missão, que, em última análise, parece predispô-lo a uma contínua práxis transformadora de situações concretas em realidades simbólicas. A profissão de fé literária de Rosa reafirma sua particular tendência de materializar crenças e práticas pessoais na criação literária: "Segundo concebo, arte é coisa seriíssima, tão séria quanto a natureza e a religião" (GUIMARÃES, 1972: 137).

Parte da obra literária de Guimarães Rosa foi produzida no exterior. O fato de estar, muitas vezes, distanciado de seus mais importantes "referenciais" geográficos, lingüísticos e culturais levou-o a driblar o esquecimento, com o recurso à reminiscência e à inventividade. Entretanto, o intuito de reinventariar e realimentar suas fontes levou-o de volta, em não raras opor- 
tunidades, ao cenário de sua infância. Numa de suas correspondências com o pai, Rosa, na carta de 6 de novembro de 1945, tematiza seu hábito de "pesquisar" e "anotar". Nessa carta, que trata de uma excursão à terra natal, ele ressalta sua preocupação em colocar-se pari passu com as tendências da modernidade crítica, sobretudo no que diz respeito às condições de exatidão documental que regulam o "fazer literário" da literatura moderna:

Creio que será uma excursão interessante e proveitosa, que irei fazer de cadernos abertos e lápis em punho, para anotar tudo o que possa valer, como fornecimento da cor local, pitoresco e exatidão documental, que são coisas muito importantes na literatura moderna. (ROSA, 1983: 159-160)

Tendo em vista um Rosa ao mesmo tempo renovador e museico, inventariador de tudo, ele nos surpreende com sua atitude paradoxal ao emitir um julgamento crítico extremamente intolerante em relação a Machado de Assis, sobre o qual ele afirma numa caderneta de notas escrita em Hamburgo, na Alemanha:

Mesmo antes de compor os seus livros, ia anotando pensamentos, frases etc., em livro ou em cadernos especiais, espécie de surrão ou alforje, de onde sacava, aos punhados, ou pinçava, um a um, os pensamentos de reserva que houvessem resistido ao tempo (processo aliás muito louvável. Tanto quanto o hábito de compulsar dicionários, visível em Machado de Assis) [...] Não pretendo mais ler Machado de Assis... Acho-o antipático de estilo, cheio de atitudes para embasbacar o indígena; lança mão de artifícios baratos, querendo forçar a nota de originalidade; anda sempre no mesmo trote pernóstico, o que torna tediosa a sua leitura. (ROSA apud CONY, 2006)

Esse excesso de rigor diante do caráter meticuloso e também inventariador de Machado de Assis revela um Rosa vaidoso, no mínimo paradoxal e quiçá atingido pela angústia da influência. Por que tamanha intolerância em relação ao Bruxo do Cosme Velho? Ora, ficou demonstrado que Rosa, não diferentemente de Machado, se dota de um fazer literário cuidado, meticuloso, arquitetando ademais um projeto literário de dimensões culturais a se concretizar e se sedimentar em longo prazo. Além de relacionar a renovação da 
língua à renovação do mundo, como já acentuamos, uma das principais metas incluídas em seu "projeto de longo alcance" era a criação de uma literatura feita para perdurar, no mínimo, até o próximo milênio.

Um dos documentos a atestar tal propósito é uma de suas cartas ao tradutor alemão Meyer-Clason, quando está a ensinar a este quais são as tarefas de um grande tradutor, talvez visando a uma grandiosa tradução do romance Grande sertão: veredas. Da carta, recortamos esta inusitada afirmativa de Rosa: "A gente tem de escrever para setecentos anos. Para o Juízo Final. Nenhum esforço suplementar fica perdido". Todavia, como se estivesse a amenizar a excessiva auto-estima, o arguto Guimarães Rosa deixa ambígua a penúltima frase, "para o Juízo Final”. Trata-se de um significante errático a deslizar da aposta para a dúvida. A temerária e de certa forma presunçosa aposta acerca-se da certeza de que o romance Grande sertão: veredas terá sua sobrevida até o fim dos tempos. Quanto à dúvida, esta encerra o temor ou, quem sabe, uma espécie de revisão auto-irônica de que essa obra, que se pretende "prima", somente terá seu derradeiro julgamento no juízo eterno, numa espécie de acerto de contas com Deus ou, mais provavelmente, com o diabo, tendo em vista o grande pacto com este entabulado no interior do Grande sertão: veredas.

No entanto, não deixa de ser curioso registrar a concepção que Rosa guarda de tradução. Descontando o viés retórico contido em sua metapoética sobre o assunto, cabe observar-lhe uma concepção difusa de apropriação, transcriação ou, na expressão rosiana, "traduzadaptação", o que faria do tradutor/escritor Guimarães Rosa um receptor antenado com o "plano das idéias" e co-autor do "grande e interminável livro" virtualmente encerrado na "Biblioteca de Babel", conforme a concebe Jorge Luis Borges em ensaio homônimo (BORGES, 1986).

Eu, quando escrevo um livro, vou fazendo como se o estivesse "traduzindo" de algum alto original, existente alhures, no mundo astral ou no "plano das idéias", dos arquétipos, por exemplo. Nunca sei se estou acertando ou falhando nessa "tradução". Assim, quando me "re"-traduzem para outro idioma,

\footnotetext{
${ }^{5}$ MEYER-CLASON. João Guimarães Rosa e a língua alemã (xerox do texto original fornecido pelo autor, em 1998). p. 111.
} 
nunca sei, também, em casos de divergência, se não foi o Tradutor quem, de fato, acertou, restabelecendo a verdade do "original ideal", que eu desvirtuara... (BORGES, 1986: 63-64).

Em entrevista a Fernando Camacho, Rosa enfoca essa temática onipresente em sua metapoética e recorrente em suas interlocuções com críticos e tradutores, revelando como, consciente ou inconscientemente, bebe da mesma água que mana de seus antecessores, dentre os quais Machado de Assis e... Walter Benjamin.

Mas ao mesmo tempo, pobre de mim, entra outra coisa, entra tanta coisa, ficando tudo misturado... Júlio Dantas, Fernando Camacho, Walter Benjamin, Rubem Braga, Magalhães Junior, Machado de Assis, Eça de Queirós. Nada é alto demais. Nem baixo demais. Tudo é aproveitável. Agora, qualquer coisa que eu leio, se eu gosto, eu começo a colaborar com o que leio, mentalmente, eu estou mudando, aproveitando, vivendo, imaginando... (ROSA apud CAMACHO, 1978: 42-53)

Para realizar sua tarefa de escritor, bem como de tradutor da biblioteca universal, Rosa, dotando-se de zelos homólogos aos de Machado de Assis, não perde nenhuma oportunidade em aplicar-se a colher dados, anotar tudo, no afã de constituir seu interminável acervo. Assim, ele urde, sob sólidos alicerces, o arcabouço poético-crítico para enfrentar os novos paradigmas estéticos que foi capaz de fundar de modo até hoje surpreendente, como se pode conferir neste trecho de carta endereçada ao tio Vicente Guimarães:

Intuitivo, à minha maneira, senti, desde muito cedo, instintivamente, quais as estradas em que meus pés caberiam; e adotei naturalmente o processo de acumular material e afiar as ferramentas, à espera de momentos propícios e decisivos, quando a oportunidade passa perto e a gente tem de segurá-la com mão firme, doidamente, como um louco que se agarrasse ao rabo de um cavalo a galope. (ROSA apud GUIMARÃES, 1972: 160)

Ao discorrer sobre o desgaste sofrido pela língua portuguesa e sugerir meios a serem empregados em sua restauração, Guimarães Rosa emprega a co- 
nhecida clave de Mário de Andrade sobre a necessidade de "amilhoramento" da nossa língua. A operação reabilitadora exige, segundo ele, uma verdadeira ginástica, quase uma operação alquímica, mediante a qual as propriedades fundamentais da língua - a plasticidade, a permeabilidade, a fluidez - possam recuperar seu tônus muscular:

É preciso distendê-la, distorcê-la, obrigá-la a fazer ginástica, desenvolver-lhe os músculos. Dar-lhe precisão, exatidão, agudeza, plasticidade, calado, motores. E é preciso refundi-la no tacho, mexendo muitas horas. Derretê-la, e trabalhá-la, em estado líquido e gasoso. (ROSA apud GUIMARÃES, 1972: 138)

Faz parte do projeto de aperfeiçoamento de Guimarães Rosa a áspera e irônica condenação aos regionalistas que teriam clicherizado o folclore nacional, uma das poucas vertentes brasileiras que, no seu entendimento, lograriam um prestígio internacional. $\mathrm{O}$ ataque se dirige ainda a quaisquer escritores que "dormiram muito e sonharam que literatura era dançar samba" (ROSA apud GUIMARÃES, 1972). A partir de um locus cuja enunciação se afina muito mais com a conservadora e elitista dicção do "diplomata" que com a do "escritor modernista", Guimarães Rosa patenteia um excessivo zelo ao criticar a preguiçosa adoção de fórmulas feitas, que, no seu ácido entendimento, confere um ar de déjà $v u$ à literatura brasileira.

Naturalmente palavrosos, piegas, sem imaginação criadora, imitadores, ocos, incultos, apressados, preguiçosos, vaidosos, impacientes, não cuidamos da exatidão, da observação direta, do domínio dos temas, do estudo prévio, do planejamento, da construção literária. Somos do alongamento, do nariz-decera, do aproveitamento, em décima ou vigésima mão, de reminiscências literárias, da literatice, enfim. (ROSA apud GUIMARÃES, 1972)

Não faltam, enfim, sinais de que Guimarães Rosa se afina muito mais que desafina com o que ele critica em Machado de Assis. Não resta dúvida de que ambos construíram uma obra literária extraordinária, tendo como suporte tanto a herança de várias tradições quanto a preocupação em inovar. E, curiosamente, como se fora um ato de transmissão ou um jogo de passar bastões, Guimarães Rosa vem justamente a falecer (ou a ficar encantado, 
conforme suas próprias palavras) em 1908, ano do falecimento de Machado de Assis. É como se, nesse sentido, houvesse um legado colonial recorrentemente enfocado por Machado a ser suplementado pelo escritor mineiro.

\section{Rosa: um escritor latino-americano}

Neste século pós-colonial, marcado pelo crescente fenômeno de mundialização e suas demandas de flexibilização de fronteiras econômicas, políticas e culturais, o Brasil e a América Latina patenteiam-se como modelo de heterogeneidade cultural, de hibridismo étnico e lingüístico. Tais valores, fortemente explorados em Grande sertão: veredas, revelam-se aptos a desencadear uma nova aliança de singularidades e disponibilizar as bases utópicas para o redimensionamento de novas redes locais e internacionais. Em janeiro de 1965, Guimarães Rosa participa, em Gênova, do $1^{\circ}$ Congresso de Escritores Latino-Americanos, durante cujos debates surge a aporia sobre o engajamento político de intelectuais e escritores da América Latina. É nesse contexto de conflitividade que Rosa concede a Günter Lorenz uma longa entrevista. Entremeada por assuntos como língua, literatura, diplomacia, política, biografia, tradução, regionalismo, brasilidade, a entrevista deixa entrever, em seu vasto temário, a preocupação de Rosa com os rumos da identidade literária e cultural da América Latina, vaticinando, num tom acentuadamente utópico, que, no ano 2000, ela se libertaria da fatalidade de estar há séculos sob dependência literária e cultural.

Estou firmemente convencido, e por isso estou aqui falando com você, de que no ano 2000 a literatura mundial estará orientada para a América Latina; o papel que um dia desempenharam Berlim, Paris, Madri ou Roma, também Petersburgo ou Viena, será desempenhado pelo Rio, Bahia, Buenos Aires e México. O século do colonialismo terminou definitivamente. A América Latina inicia agora o seu futuro. Acredito que será um futuro muito mais interessante, e espero que seja um futuro humano. (ROSA, 1994: 61) 


\section{Bombas, genocídio e diplomacia}

Em 1938, Guimarães Rosa é nomeado cônsul adjunto em Hamburgo, onde conhece Aracy Moebius de Carvalho, que se tornaria sua segunda esposa. Durante a II Guerra Mundial, por várias vezes escapou da morte; um dia, ao chegar ao consulado, só encontrou escombros, o que aparece em seu diário da Alemanha, em 15 de setembro de 1941: “Alarme, às 10 35' da noite... Tiros, tiraços, tirambaços. Bombas! Bombas e mais bombas. Balbúrdia de Warnungs e Entwarnungs. Gás?! Não, desarranjo de sirenes! Partidas as janelas do consulado".

Embora consciente dos perigos que enfrentava em Hamburgo, protegeu e facilitou a fuga de judeus perseguidos pelo nazismo; nessa empresa, contou com a ajuda de Aracy. Em reconhecimento, o diplomata (já falecido) e sua mulher foram homenageados em Israel, em abril de 1985, com a mais alta distinção concedida pelo governo israelense para prestar gratidão àqueles que se arriscaram para salvar judeus perseguidos pelo nazismo. $\mathrm{O}$ nome do casal foi dado a um bosque situado nas encostas que dão acesso a Jerusalém. Segundo a senhora Aracy, que compareceu à homenagem, seu marido sempre se absteve de comentar o assunto, visto seu pudor em falar de si mesmo. Apenas dizia: "Se eu não lhes der o visto, vão acabar morrendo; e aí vou ter um peso em minha consciência". Consciência que já lhe vinha pesando quando, conforme registrado no diário da Alemanha, começa a notar uma política de recrudescimento contra os judeus: "Ontem [20.IX.1941] começou a obrigação do distintivo na roupa dos judeus [com duas suásticas desenhadas, sendo a segunda um pouco maior, com a palavra "judeu” escrita dentro]". Nesse sentido, cabe ainda assinalar que Rosa vai crescentemente se cientificando do cruel destino que a Gestapo reservará aos judeus, conforme se pode detectar neste seu importante registro histórico:

Os judeus não teem o direito de comer todas as coisas que ainda estão ao alcance dos estômagos arianos. As "cartas-de-comida" dos semitas são sobrecarimbadas com um J rubro. Eles não recebem cartas para ovos, nem Nahrmittel; as distribuições de carne a mais eles também não ganham. Assim como Bezugschein para roupas (ou Punkle) eles não recebem, nem solas para sapatos. Não podem possuir aparelhos de rádio; não podem sair de casa de- 
pois das oito horas da noite. Teem de fazer as compras em certas casas fixadas, onde muitas vezes não há mais nada para se comprar... mas sempre há, caso o pobre diabo esteja disposto a pagar mais. ${ }^{6}$

Na já mencionada entrevista, Günter Lorenz indaga a Rosa qual o estratagema por ele adotado na II Guerra, enquanto cônsul adjunto em Hamburgo: "Foi isto [ou seja, a desumanidade da política e dos políticos, sobre os quais Rosa anteriormente expressara sua aversão] que em Hamburgo levou você a se arriscar perigosamente, arrebatando judeus das mãos da Gestapo?” (ROSA, 1994: 41).

Em resposta, Guimarães Rosa patenteia sua porção revolucionária e mesmo beligerante, ainda que mediada (quiçá domada) pela diplomacia:

Foi alguma coisa assim, mas havia também algo diferente: um diplomata é um sonhador e por isso pude exercer bem essa profissão. O diplomata acredita que pode remediar o que os políticos arruinaram. Por isso agi daquela forma e não de outra. E também por isso gosto muito de ser diplomata. E agora o que houve em Hamburgo é preciso acrescentar mais alguma coisa. Eu, o homem do sertão, não posso presenciar injustiças. No sertão, num caso desses imediatamente a gente saca o revólver, e lá isso não era possível. Precisamente por isso idealizei um estratagema diplomático, e não foi assim tão perigoso. E agora me ocupo de problemas de limites de fronteiras e por isso vivo muito mais limitado. (ROSA, 1994: 41-2)

Em vista de preocupações literárias culturais e políticas como essas, mas também de seu refinamento técnico; de seu poliglotismo; da criativa conjunção entre as formações discursivas da tradição oral e os recursos poéticos das vanguardas européias; da desmarcação dos limites territoriais e da cor local do nosso regionalismo naturalista; da utilização de procedimentos recursivos capazes de agenciar novas redes de sentido e de trocas culturais, Guimarães Rosa criou muitos paradigmas estéticos, que em muito o puseram à frente de seu

\footnotetext{
${ }^{6}$ ROSA. Anotações na p. 54 do diário de guerra, escrito em Hamburgo, na Alemanha. Em Guimarães Rosa Cadernos. Acervo de Escritores Mineiros, Biblioteca Central/UFMG.
} 
tempo, tornando-o contemporâneo ao século XXI. Por isso e pela grande rede de sentidos com que sua obra institui novas formas de comércio simbólico e cultural entre o sertão e o mundo, Guimarães Rosa marcou para sua "aldeia" um exponencial e honroso lugar na galeria da literatura universal.

\section{A letra da dávdiva}

O suplemento entre o local e o universal, entre a beligerância, a história, a política e a diplomacia, entre a tradição oral e a refinada escrita literária, entre o real e o simbólico poderia ser metaforizado em várias passagens de Grande sertão: veredas. No entanto, um dos mais extraordinários lances de dados, pedras, perdas e trocas, com o evidente e muito bem elaborado manejo de Guimarães Rosa, no sentido de saldar a "letra" que sela a dívida concreta (de)legada pelo pai/padrinho/colonizador, está no episódio das pedras semipreciosas que mudam, transmudam e transluzem ao longo do romance. Esse episódio de extraordinária riqueza significante vai-se desenrolando em similitude com um jogo de "passa-anel", e nele uma "dádiva" de amor transforma-se, pelas mãos e pela fala de Riobaldo, em "dívida". Esta, por sua vez, retorna sob a forma de uma letra móvel que vai sobrar em "dávdiva", forma híbrida e superposta de "dádiva" e "dívida". Investido de flutuantes e desdobráveis estratégias discursivas a agenciar o hábil jogo de constelaridade entre duplos suplementares e ecoantes, o sujeito da enunciação condensa - na ambivalência da dávdiva - dádiva e dívida, pedra e perda, troco e troca, (o) erro e (eu) erro, Davi e Diva, ou seja, o masculino e o feminino espelhados e anagramáticos de "vida". Trata-se indubitavelmente de um deslizamento tropológico em que a metáfora é ligeiramente metonímica e a metonímia ligeiramente metafórica, em que o suplemento constituído pela letra que falta faz fulgurar pedras, perdas, trocas, nomes e cores. Ademais, o significante e o significado também se realimentam nessa caixa de ressonância, em que a materialidade do signo tira o peso das pedras para refundi-lo em música e plumagens.

Toda essa superposição desdobrável se constrói basicamente da seguinte forma: Riobaldo compra uma pedra "safira" em Araçuaí e a dá de presente a Diadorim. Não obstante a paixão pela “donzela guerreira” (GALVÃO, 1998: 12-3 e 187-8), nosso herói está convicto, em sua cegueira, de que ela é ele, e 
o amor entre os dois - dois machos - é uma impossibilidade. Diadorim lhe pede para guardar a pedra, sugerindo que, assim que puder revelar-lhe "um segredo", irá aceitá-la definitivamente. Entretanto, mais tarde, Riobaldo usa a mesma pedra para selar seu noivado com Otacília.

A cada vez que a pedra se desloca, o herói falho, sem o perceber, troca-lhe o nome (na primeira vez em que menciona o assunto "pedra", Riobaldo fala em "pedras turmalinas" de Araçuaî). Nesse processo de transmutação de pedras que o narrador coloca em seu próprio caminho, a "safira" vira "topázio" e depois "ametista". Quando, mais tarde, as dívidas de nosso devedor retornam como alguma coisa que falta, o ato falho aflora na forma ambígua de "erro e troco". No triz do espanto disso que inesperadamente atravessa um real imprevisto, o sentido estorna como ressentido implicando o erro e o troco. $\mathrm{Ou}$ (eu) erro e troco, formas ambíguas que se multiplicam em formas substantivas e respectivamente verbais e que, a partir do deslizamento metonímico, vão aflorar como o suplemento gerador de nova produção de sentido. Assim, um significado inesperado, inaudito e errante ${ }^{7}$ decalca, na materialidade da pedra, o signo do fulgor significante de toda uma história de recalque, foraclusão e perda, como revela o trecho abaixo.

Otacília a tudo estava exposta, por culpa de maus conselhos. - O seo Habão entregou a ela a pedra de ametista... - eu falei. Alto falei; e não queria que o Alaripe ressoasse: “... entregou a ela a pedra...” Isto é: a pedra era de topázio! - só no bocal da idéia de contar é que erro e troco - o confuso assim. Diadorim sofria mais de tudo, quem sabe, por conta da dávdiva daquela pedra. Otacília não devia de ter vindo. Eu - Essas andanças! (ROSA, 1984: 531, dois últimos grifos meus)

\footnotetext{
7 Talvez, mais do que significado, a passagem seja um caso de Significancia. Trata-se de um conceito da semiótica desenvolvido em 1969 por Julia Kristeva, segundo a qual, diferentemente de significaşão, produção de sentido resultante do sentido imanente e manifesto no texto, a significância se institui enquanto um processo em que significantes produzem não novos sentidos, mas novos significantes. Produção móvel, à deriva, a significância responde à necessidade do sujeito errático de enunciação, dotando-o da aptidão para a constituição de uma nova cadeia de significantes, como a que surpreendemos na voz do enunciador de Grande sertão: veredas. Na produtividade do texto em significância, haveria uma dupla articulação: uma responsável por recobrir o plano do enunciado, constituído pelo discurso manifesto; e outra a dar materialidade aos jogos subjacentes a essa estrutura aparente (cf. KRISTEVA, 1978).
} 
É de notar que, em sua leitura intersemiótica do romance Grande sertão: veredas, o artista plástico Arlindo Daibert representou esse episódio numa pintura intitulada "Pedras turmalinas", em que aparece uma pedra maior e abaixo dela várias pedras menores, que vão, por sua vez, mudando de cor. $\mathrm{Na}$ opacidade da pedra maior, várias letras se mesclam, sugerindo a matização e a superposição dos nomes das pedras: safira, topázio, ametista. Segue abaixo a reprodução da pintura de Daibert.

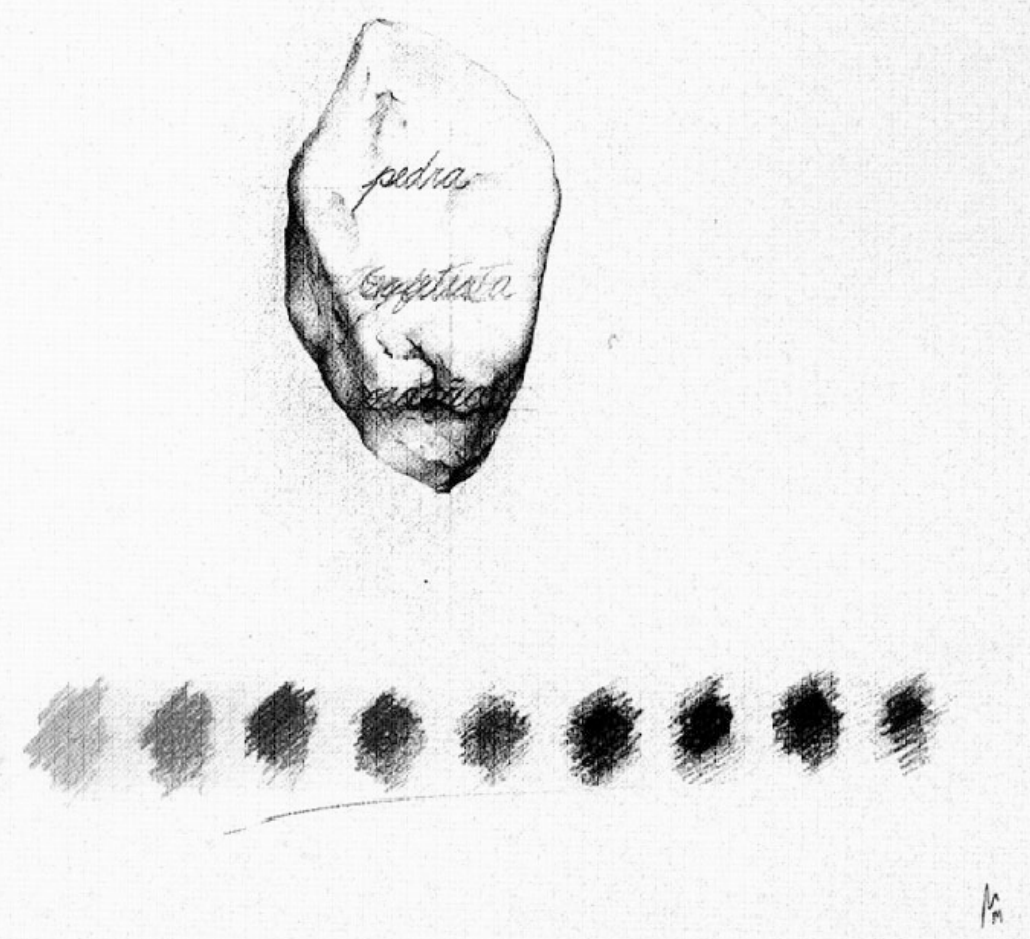

Figura 2. Detalhe da gravura "A pedra de turmalina". Reproduzido de: DAIBERT, Arlindo. Imagens do Grande Sertão. Belo Horizonte: UFMG, 1998. p. 67.

Pactário, traidor e devedor inadimplente (como o narrador-protagonista do romance Dom Casmurro, de Machado de Assis), o narrador da obra-prima rosiana coloca-se na posição ambígua de assimilação e resistência à tradição e aos 
preceitos de um legado colonial pelo qual é cobrado, mas do qual não se aceita devedor. Trocar de letra, mudar os nomes, trocar as pedras com que esbarra no meio do caminho é uma forma insurgente de reformular uma longa história de dependência político-econômica e provocar novas formas de trocas simbólicas e culturais em nosso legado colonial, lingüístico e estético.

\section{Referências Bibliográficas}

ANDRADE, Carlos Drummond de. Um chamado João. Correio da Manhã, Rio de Janeiro, 22 nov. 1967.

BORGES, Jorge Luis. "A biblioteca de Babel”. In: Fiç̧ões. Tradução de Carlos Nejar. Porto Alegre: Globo, 1986.

CAMACHO, Fernando. "Entrevista com Guimarães Rosa". Humboldt, Berna, n. 37, p. 42-53, 1978.

CONY, Carlos Heitor. Rosa e Machado. Folha de São Paulo, São Paulo, 23 maio 2006. Caderno 1.

COUTINHO, Eduardo F. Guimarães Rosa: um alquimista da palavra. In: ROSA, João Guimarães. Ficção completa. 3 v. Rio de Janeiro: Nova Aguilar, 1994. v. I. . (Org.). Guimarães Rosa. Rio de Janeiro: Civilização Brasileira, 1991.

DAIBERT, Arlindo. Imagens do grande sertão. Belo Horizonte: UFMG, 1998.

GALVÃO, Walnice Nogueira. A donzela-guerreira: um estudo de gênero. São Paulo: Senac, 1998.

GUIMARÃES, Vicente de Paulo. Joãozito: infância de João Guimarães Rosa. Rio de Janeiro: José Olympio, 1972.

JIMÉNEZ, José Miguel. "El Che”. Disponível em:

$<$ http://www.margencero.com/musica/che/che_biografia.htm>. Acesso em: 1 set. 2006.

KRISTEVA, Julia. Semeiotike: recherches pour une sémanalyse. Paris: Seuil, 1978.

MACHADO DE ASSIS, J. M. Dom Casmurro. In: COUTINHO, Afrânio (Org.). Machado de Assis: obra completa. 3 v. Rio de Janeiro: José Aguilar, 1959. v. 1.

MEYER-CLASON, Curt. João Guimarães Rosa e a lingua alemã. (Xerox do texto original fornecido pelo autor, em 1998.)

RAMA, Ángel. Transculturación narrativa en América Latina. Montevideo: Arca Editorial, 1989. 
ROSA, João Guimarães. Ficção completa. 2 v. Rio de Janeiro: Nova Aguilar, 1994. v. 1. Diálogo com Guimarães Rosa.

. Grande sertão: veredas. 21. ed. Rio de Janeiro: Nova Fronteira, 1984.

ROSA, Vilma Guimarães. Relembramentos: João Guimarães Rosa, meu pai. Rio de Janeiro: Nova Fronteira, 1983.

SCHWARZ, Roberto. "Grande-sertão: a fala”. In: COUTINHO, Eduardo F. (Org.). Guimarães Rosa. Rio de Janeiro: Civilização Brasileira, 1991. 
